\title{
Utilization of Corn Cobs Ash as Cementitious and Binary Cementitious Materials in Concrete and Cement-based Composites: A Review
}

\author{
Abba Nuhu ${ }^{1 *}$, Nuradden Shehu' ${ }^{2}$, Allan Joseph Usman ${ }^{3}$ \\ 1Department of Building Technology, Federal Polytechnic, Kaura Namoda, Zamfara State, Nigeria \\ ${ }^{2}$ Department of Building Technology, Nuhu Bamalli Polytechnic, Zaria, Kaduna State, Nigeria \\ ${ }^{3}$ Department of Architectural Technology, Federal Polytechnic, Nasarawa, Nasarawa State, Nigeria \\ *Correspondence: Abba Nuhu, abbanuhu333@gmail.com, School of Environmental Studies, Federal Polytechnic, Kaura \\ Namoda, Zamfara State, Nigeria
}

Received: $18 / 04 / 2021$

Accepted: (online first): 25/05/2021

Vol./Issue/Year: 2(1), 2021

Competing interests: Author(s) stated no compete of interest.

Edited by: Lowy, A.D., Mátyás, B. Copyright 2021 @ The Author(s). This is an Open Access article under the CC-BY 4.0 license published by Genesis Sustainable Future Ltd. a private company limited by shares organized and existing under the laws of Hungary, with its head office located at 33 Rákóczi, H-3950 Sárospatak, Hungary and company registration number: 05-09-033278.

How to cite: Abba Nuhu, A.,Shehu, N., Usman, A.J. Utilization of Corn Cobs Ash as Cementitious and Binary Cementitious Materials in

Concrete and Cement-based Composites: A Review. DRC Sustainable Future, 2021, 2(1): 26-; DOI: 10.37281/DRCSF/2.1.4

\section{ABSTRACT}

This paper reviews the utilization of corn cobs ash (CCA) as pozzolanic, cementitious, and binary cementitious materials in concrete. CCA is the grey-to-brown, inorganic or heterogeneous residual material derived from the hightemperature incineration or combustion of corn cobs (CC). Despite the typical problematic nature of biomass ash, the chemical composition of CCA renders it a potential pozzolanic material. Therefore, numerous studies have critically examined the process technologies and operational conditions for CCA production and its application as a partial replacement for cement in concrete. Other studies have extensively characterized the physicochemical, morphological, microstructure, and thermal properties of CCA through various analytical techniques. Potential pozzolanic materials must meet the condition: $\mathrm{SiO}_{2}+\mathrm{Al}_{2} \mathrm{O}_{3}+\mathrm{Fe}_{2} \mathrm{O}_{3} \geq 70 \%$, according to ASTM C618, to which CCA complies satisfactorily. Hence, the use of CCA as a replacement for cement has been investigated over the years. Findings indicate that the partial replacement of cement with CCA decreases compressive strength, thermal conductivity, ultrasonic pulse velocity, and density of the hardened concrete at normal temperatures. Nevertheless, the thermal treatment (calcination) of CCA and extended curing enhances compressive strength owing to higher silica content and extended surface area. Besides, the partial replacement of cement with CCA enhances the insulation properties of mortar, which improves thermal comfort, costs and energy savings in buildings. Hence, the partial replacement of cement with CCA provides an environmentally friendly, low cost, and sustainable approach for valorizing CC residues whilst addressing $\mathrm{CO}_{2}$ emissions in construction.

Keywords: CCA ash, Concrete, Corn Cobs, $\mathrm{CO}_{2}$, Pozzolanic, ASTM 


\section{Introduction}

Corn, otherwise known as Maize (Zea mays L.), is a tall cereal plant or annual grass characterized by a stout, erect, solid, and internodal stem that grows up to heights ranging from 3-13 $\mathrm{m}$ (or 10-43 ft) (von Cossel et al., 2017; Wasaya et al., 2017). The plant is considered a short day and facultative cultigen. Its leaves are large but narrow with curly margins that are spaced interchangeably on reverse sides of the stem. The male flowers formed on the tassel, which terminate at the major base on the stem, are developed based on the selected day of growing degrees in a specifically adapted environment (Hung et al., 2012; Karl, 2002). In contrast, the female flowers that eventually become the ears are characteristically thick axis spikes or pair of spikelets that eventually become rows of grain (Saldivar, 2016; Young et al., 2004).

Leaf-bearing stems of the corn plant generate distinct pollen and ovuliferous inflorescences that yield numerous seeds or kernels, which grow on cone-shaped structures called cobs or ears. Each ear or cob comprises around 200-400 seeds of variable color (e.g., white, blue-grey, red, black, and yellowish), with dimensions ranging in length from 100 to $250 \mathrm{~mm}$, according to the variety (NWE, 2020). In principle, the ears are clusters of female flowers, enclosed and protected by numerous sheets2 ofdeaves that remain hidden until the pale-yellow silks emerge during growth and development (Freeling et al., 2013). Nonetheless, the flowers can undergo transformations (typically known as ts4 and ts6 mutations) into hermaphrodite (or male to female flowers in a tassel) that can hamper stamen development as opposed to the pistil (Chuck et al., 2007; Irish, 1997). The plant is scientifically classified on the taxonomic basis as Magnoliophyta, Liliopsida, Poales, Poaceae, and Zea, which correspond to its division, class, order, family, and genus, respectively. Corn is typically regarded as one of the first genetically modified food crops known to mankind, which has resulted over the years in numerous drought-resistant, insect and diseaseresistant varieties, otherwise termed hybrid cultivars (Iken et al., 2004; Yadav et al., 2015). Historical records indicate that the plant was originally domesticated around 3,500 B.C. from the annual teosinte, Zea mays ssp. parviglumis, native to central and southern Mexico (Ali et al., 2020). Due to its Native American origin corn is often also described as Indian corn or simply as maize by the Arawak tribes of Native America, whereas others report that the word maize is derived from Spanish, based on the indigenous Taino word for the plant, mahiz (Herbst et al., 2007; NWE, 2020).

Cultivation and processing of corn have spread widely over the years from its ancestral epoch in Mesoamerica to become an important globalized food crop (Shiferaw et al., 2011). According to the United Nations Food and
Agricultural Organization (UN-FAO), the total global production of corn was 1.5 billion tons in 2018 but has declined to 1.07 billion in 2020 (FAOSTAT, 2020; Knoema, 2020). The largest global producers (i.e., top 5) of corn, namely the United States, China, Brazil, Argentina, and Ukraine account for over $75 \%$ of global production. Furthermore, corn is cultivated on almost 100 million hectares of land located in most developing countries. Consequently, corn is considered the leading grain and most cultivated cereal crop in the world (Saldivar et al., 2016; Shiferaw et al., 2011). The high acreage, cultivation, and tonnage of global corn stocks are particularly ascribed to advances in genetic engineering along with the plant's high adaptability, diversity, and demand (Hardeman, 1999; Saldivar, 2016). The UN-FAO states that large quantities of corn are cultivated and processed for numerous applications, such as direct human consumption (13.8\%), food production (19\%), livestock feeds (54\%), biofuels (14\%), chemicals, pharmaceuticals, and building materials, among other uses worldwide (Saldivar et al., 2016). According to analysts, the global demand and production of corn, particularly in developing countries, are projected to double by the year 2050, owing to demographic dynamics such as population growth, higher living standards, and urban drifts (Shiferaw et al., 2011).

Conversely, the cultivation and processing of corn generate large quantities of solid wastes or stover comprising leaves, stems, and cobs, which account for over half the mass of the plant. These waste streams are utilized as animal feeds, mulching materials, organic manure, and cooking fuel (Jansen et al., 2012). Other notable strategies for utilizing corn waste streams include landfilling, field dumping, and open combustion (Kapoor et al., 2016; Santiago-De la Rosa et al., 2017). Combustion of agricultural residues generates soot or particulate matter (PM) and greenhouse gases that pose a grave danger to human health, safety, and well-being. Such practices result in the loss of soil-plant nutrients and microbial obliteration, which severely affect the ecosystem (Domínguez-Escribá et al., 2010; Kapoor et al., 2016). Hence, the under listed strategies for exploiting these wastes are considered inefficient and unsustainable (Bhuvaneshwari et al., 2019; Jain et al., 2014). The ineffectiveness of the current strategies has also resulted in the underutilization of large volumes of these waste streams, which pose severe dangers to flora, fauna, and the environment at large (Ali et al., 2020).

Furthermore, the poor fuel properties, namely high moisture content, low energy density, and transport and handling of corn wastes affect its utilization as biofuels for bioenergy (Meng et al., 2019; Porteiro et al., 2010). Likewise, several studies have shown that the ash content of biomass, such as corn cobs could pose 
technical problems during combustion and gasification. Notably, the biomass ash causes bed agglomeration, fouling, sintering, and clinker formation, which lower the conversion efficiencies and operational maintenance of such biomass technologies (Lu et al., 2015; Nyakuma et al., 2017). Alternatively, numerous researchers have sought to utilize corn cob ash (CCA) as cementitious materials in the bid to address current challenges of waste disposal, management, and valorization of maize residues. Therefore, this paper is needed by experts in the field, as it provides an overview of the status and challenges of utilizing CCA as cementitious materials in concrete. Furthermore, it gives insights into the future use of CCA.

\section{Corn Cobs: Overview and Current Uses}

Corn cob (CC) is the solid cone-shaped residue generated from the threshing of the corn kernels (Bakharev et al., 2020; NIIR, 2006; Yu et al., 2015). The internal structure of $\mathrm{CC}$ is characterized by a white appearance, whereas the outermost part of the $\mathrm{CC}$ can range from yellow, beige, yellow to purple, depending on the variety (Ajao et al., 2016; Salvador-Reyes et al., 2020). It is also considered the central core of the maize ear with a residual yield of 1.42-1.53 dry tons per hectare. Consequently, corn cobs are major by-products of corn processing, which account for 20-30\% (along with the outer leafy covering of corn called husks) by weight of the corn plant (Kapoor et al., 2016; Samanta et al., 2012). Da Silva et al. (2015) report that typically $180 \mathrm{~kg}$ of corn cob are generated from the processing of 1 ton of corn ear. This quantity amounts to over 140 million tons annually. The bulk of the CC generated annually is currently utilized for the production of fine chemicals, e.g., furfural (Zhang et al., 2019; Zhang et al., 2020), agrochemicals, such as pesticides and rodenticides (Jacob et al., 2018; Nasser, 2018), livestock fodder (Garantjang et al., 2020; Wachirapakorn et al., 2016), farmhouse beddings (Kapoor et al., 2016; Pallas et al., 2020), biofuels, such as ethanol and charcoal (Kluska et al., 2020; Li et al., 2018), soil enhancers (Amoakwah et al., 2017; Shen et al., 2019), and adsorbents (Ji et al., 2015; Nethaji et al., 2013), and other applications.

The utilization of $\mathrm{CC}$ in the outlined applications is a result of its ultimate, proximate, and calorific properties summarized from the most cited references, published from 2011 to 2020, with details listed in Table 1. The abbreviations M, VM, FC, AS, C, H, N, S, O, and HHV stand for moisture, volatile matter, fixed carbon, ash, carbon, hydrogen, nitrogen, sulfur, and oxygen contents (all in wt.\%), and higher heating value $(\mathrm{MJ} / \mathrm{kg}$ ) for $\mathrm{CC}$.
As revealed by data in Table $1, \mathrm{CC}$ contains volatile matter, fixed carbon, carbon, hydrogen, and higher heating values are typically in the range of $60.30-87.76$ wt.\%, 9.41-32.13 wt.\%, 41.00-53.15 wt.\%, 2.01-6.54 wt. $\%$, and $16.46-18.84 \mathrm{MJ} / \mathrm{kg}$, respectively, which enhance renewable energy recovery via thermochemical conversion into fuel gases by using gasification, pyrolysis, and combustion technologies. The presence of oxygen results, however, in the oxidative conversion of nitrogen and sulphur into gaseous pollutant oxides such as $\mathrm{NO}_{\mathrm{x}}, \mathrm{SO}_{\mathrm{x}}$, and $\mathrm{N}_{\mathrm{x}} \mathrm{O}_{\mathrm{y}}$ along with carbon and hydrogen, released during the production of ash. As observed, the ash and mineral matter in $\mathrm{CC}$ is typically between 1.05-13.70 wt.\%, which cause operational problems, including the formation of eutectics in the hightemperature thermochemical conversion processes, such as gasification. Nevertheless, the ash generated from the conversion of CC could be utilized as cementitious or pozzolanic materials (otherwise termed pozzolans) or as a replacement for cement in concrete, widely used in the construction industry.

Over the years, the quest for sustainability in the building and construction sector has stimulated the search for alternatives to cement. Studies have shown that cement accounts for $3-7 \%$ of the global $\mathrm{CO}_{2}$ emissions from the construction industry (Hanle et al., 2004). Typically, it is estimated that 0.9 tons of $\mathrm{CO}_{2}$ are released while producing 1 ton of cement (Benhelal et al., 2013). According to the study by Andrew (2018), the global emissions from the cement production process are $1.45 \pm 0.20$ Gigatons of $\mathrm{CO}_{2}$ in the year 2016, which is equal to about $4 \%$ of fossil fuel-based emissions. However, the cumulative $\mathrm{CO}_{2}$ emissions for the sector amounts to $39.3 \pm 2.4$ Gigatons from 1928 to 2016 . As a result, the cement industry is considered one of the largest sources of anthropogenic $\mathrm{CO}_{2}$ or emissions after the fossil-based fuels and land use changes (Andrew, 2018; Mikulčić et al., 2012; Zhang et al., 2014). Carbon dioxide emissions are largely ascribed to the calcination reactions of raw materials and the combustion of process fuels required during cement production (Zhang et al., 2014). Hence, there is a growing global call for the development and deployment of strategies that can mitigate $\mathrm{CO}_{2}$ emissions originating from the cement industry (Benhelal et al., 2013; Deja et al., 2010). For example, the European Union has called for the ratification and implementation of the "Best Available Techniques (BAT)" in industrial cement and lime production (Schorcht et al., 2013; Valderrama et al., 2012). The reference document proposes reduced fuel consumption, low organic raw materials selection, and the utilization of low carbon heating values to replace coal (Giner-Santonja et al., 2019; Schorcht et al., 2013). 
Table 1. Ultimate, Proximate and Calorific Properties of Corn Cobs

\begin{tabular}{ccccccccccc}
\hline References & $\mathbf{M}$ & $\mathbf{V M}$ & $\mathbf{F C}$ & $\mathbf{A S}$ & $\mathbf{C}$ & $\mathbf{H}$ & $\mathbf{N}$ & $\mathbf{S}$ & O & HHV \\
\hline Aboyade et al. (2011) & 6.50 & 80.20 & 16.70 & 3.10 & 49.00 & 6.00 & 0.30 & 0.08 & 44.70 & 17.20 \\
Wang et al. (2012) & 0.00 & 79.65 & 17.75 & 2.61 & 47.26 & 6.39 & 0.54 & 0.10 & 43.11 & 18.84 \\
Song et al. (2013) & 5.93 & 75.22 & 18.95 & 5.83 & 46.53 & 5.91 & 0.94 & 0.14 & 36.72 & $* *$ \\
Biagini et al. (2014) & 10.10 & 80.06 & 17.82 & 2.12 & 47.60 & 6.10 & 0.52 & $* *$ & 45.78 & 18.56 \\
Barontini et al. (2015) & 0.00 & 80.10 & 17.80 & 2.10 & 47.60 & 6.10 & 0.50 & 0.00 & 45.80 & 17.30 \\
Shariff et al. (2016) & 7.14 & 87.76 & 11.19 & 1.05 & 43.81 & 6.54 & 0.77 & 0.69 & 48.19 & 16.46 \\
Munir et al. (2017) & 4.01 & 79.02 & 14.77 & 2.02 & 43.63 & 6.07 & 0.00 & 0.19 & 44.08 & 17.61 \\
Dutta et al. (2018) & 2.21 & 64.24 & 32.13 & 1.42 & 53.15 & 2.01 & 0.12 & $* *$ & 23.73 & $* *$ \\
Dai et al. (2019) & 0.00 & 85.72 & 9.41 & 4.87 & 44.31 & 6.38 & 0.36 & 0.00 & 44.44 & 18.66 \\
Sattar et al. (2020) & 7.30 & 60.30 & 18.70 & 13.70 & 41.00 & 6.10 & 1.50 & 0.40 & 30.00 & 17.10 \\
\hline
\end{tabular}

Other notable schemes, such as the Best available techniques (BAT) Emission levels associated with the best available techniques (BAT-AELs), Industrial Emissions Directive (IED) and the Industrial Pollution Prevention and Control Directive (IPPCD) are also aimed to curb emissions from the cement industry (Calvo et al., 2021). Largely, these initiates propose the deployment of the three-pronged process-energymaterials approach, which involves carbon sequestration, energy-saving, and the use of alternative materials (Benhelal et al., 2013; Calvo et al., 2021). According to the authors, the transition from the wet to dry calcination process could reduce energy utilization by $50 \%$, while reducing $\mathrm{CO}_{2}$ emissions from cement production by up to $20 \%$. Unfortunately, technoeconomic challenges and prohibitive costs of carbon capture storage (CSS) have prevented thus far largescale implementation. Lastly, the materials aspect involves the partial replacement or complete utilization of alternative materials, including agricultural wastes for cement production. All the above are considered efficient measures for limiting $\mathrm{CO}_{2}$ emissions in the industry (Benhelal et al., 2013; Deja et al., 2010; Zhang et al., 2014). The most notable examples of such agricultural wastes include the lignocellulosic residues and secondary materials generated from global cultivation, processing, and valorization of corn globally. The next section of the paper presents details on corn cob ash (CCA) and its utilization as cementitious materials in concrete.

\section{Corn Cob Ash (CCA)}

Corn cob ash (or CCA) is defined as the grey-to-brown residues or materials obtained from incineration or combustion of corn cob (CC) residues. The hightemperature process of CCA production involves the thermal degradation of lignocellulosic components of $\mathrm{CC}$ into a heterogeneous mix of inorganic materials or mineral matter. Figure 1 displays the CCA produced from the $\mathrm{CC}$ combustion process.
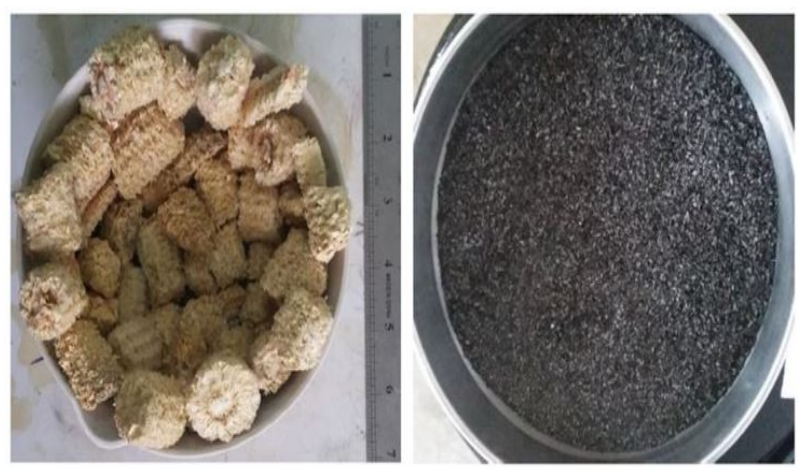

Figure 1. Corn Cobs and CCA (Memon et al., 2019)

The reaction pathway, thermal degradation mechanism, and mass/energy balance of the CCA production are presented in Figure 2. Mass and energy balances were computed based on the average high heating value of CC is $17.72 \mathrm{MJ} / \mathrm{kg}$, whereas in Table 1 ash and moisture contents are 3.882 wt. $\%$ and 4.319 wt.\%, respectively. Typically, the process begins with the heating of $\mathrm{CC}$ from ambient temperatures to $105 \pm 5{ }^{\circ} \mathrm{C}$ where drying occurs, surface-bound water being eliminated. Next, dried CC undergoes devolatilization, which thermally degrades volatile organic matter content (see Table 1) along with depolymerizing and decarbonizing hemicellulose, cellulose, and lignin to high-carbon content char. This second stage termed pyrolysis or carbonization, is typically conducted at temperatures from $105{ }^{\circ} \mathrm{C}$ to $600{ }^{\circ} \mathrm{C}$, yielding char and releasing fuel gases; hydrogen $\left(\mathrm{H}_{2}\right)$, carbon monoxide $(\mathrm{CO})$, methane $\left(\mathrm{CH}_{4}\right)$, and carbon dioxide $\left(\mathrm{CO}_{2}\right)$ along with tar or biooil. The third stage involves the oxidation or combustion of char at high temperatures (typically $600{ }^{\circ} \mathrm{C}$ to 1000 ${ }^{\circ} \mathrm{C}$ ) to ash, mineral matter, and flue gases comprising primarily $\left(\mathrm{CO}_{2}, \mathrm{CO}, \mathrm{NO}_{\mathrm{x}}\right.$, and $\left.\mathrm{SO}_{\mathrm{x}}\right)$. 


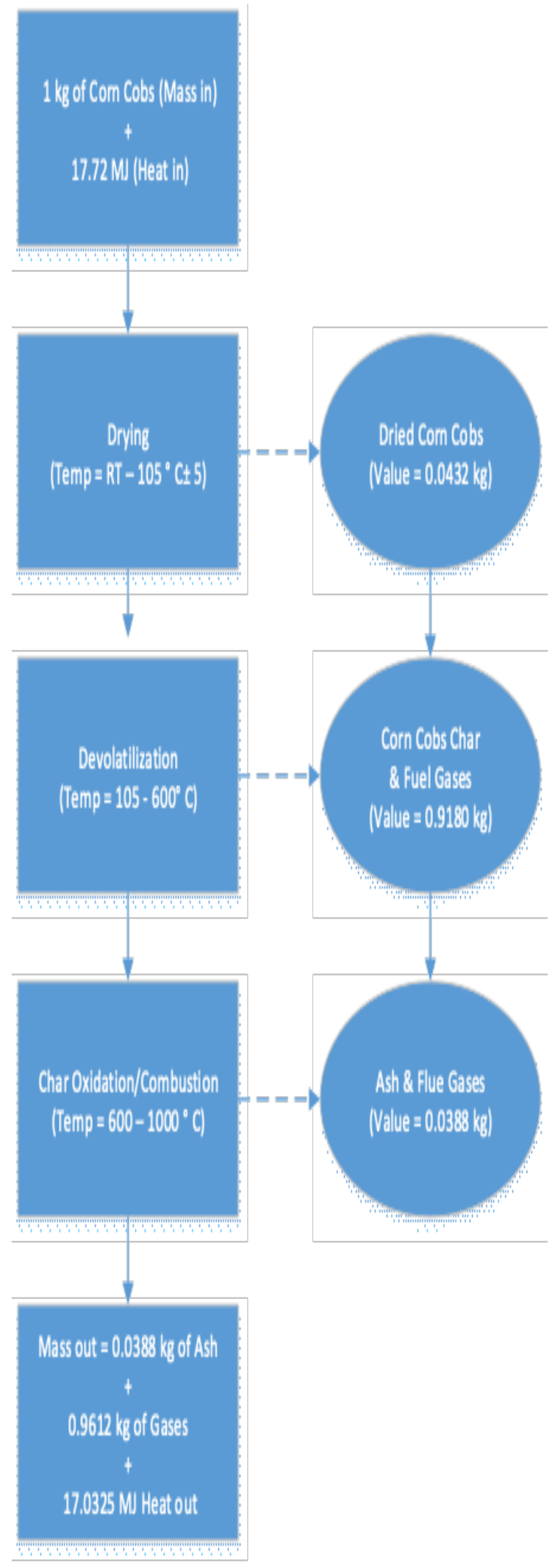

Figure 2. Process Flow, Reaction Pathway and Mass/ Energy Balance of CCA production.

In practice, various research groups have investigated the conversion of CC into CCA using different reaction parameters, reactors, obtaining dissimilar yields and distribution of the products. Numerous reaction parameters and process conditions employed during the CCA production process are summarized in Table 2 . CCA production typically occurs through either controlled or uncontrolled burning or combustion of CC. The most common reactor used is the muffle furnace, owing to its capacity to ensure safe, secure, and controlled combustion of CC into CCA. Other reactors reported in the literature include rotary drums, fabricated chambers, charcoal-fired ovens, and open-air burning, as well. Analysis of reaction parameters revealed that the combustion of $\mathrm{CC}$ to $\mathrm{CCA}$ normally takes place at temperatures from 450 to $750{ }^{\circ} \mathrm{C}$, although some studies mentioned temperatures above $1000{ }^{\circ} \mathrm{C}$, and reaction times ranging from 2 to $10 \mathrm{~h}$. According to Suwanmaneechot et al. (2015), the selection of optimal combustion temperature and thermal treatment processes, such as calcination is critical to the quality of the ash and the cement-based composites produced. Typically, optimal values and high temperatures produce amorphous silica at high yield, large surface area and porosity. The amorphous silica possesses favorable engineering properties, because of high $\mathrm{SiO}_{2}, \mathrm{Al}_{2} \mathrm{O}_{3}$, and $\mathrm{Fe}_{2} \mathrm{O}_{3}$ content (Bessenouci et al., 2011 ; Suwanmaneechot et al., 2015). Comprehensive characterization of CCA is done using advanced techniques, to evaluate the physicochemical properties, chemical composition, and mineral matter. Hence, scanning electron microscopy (SEM) is used to examine the morphology and microstructure of CCA, whereas Xray fluorescence (XRF) determines the chemical composition and mineral matter for potential applications. Table 3 lists the metal oxides compositions of CCA determined by XRF.

As observed in Table 3, the major metal oxides typically found in the CCA are $\mathrm{SiO}_{2}, \mathrm{Al}_{2} \mathrm{O}_{3}, \mathrm{Fe}_{2} \mathrm{O}_{3}, \mathrm{CaO}$, and $\mathrm{MgO}$ as reported in the literature. For $\mathrm{SiO}_{2}$ the values typically range from $38.80 \mathrm{wt} . \%$ to $67.41 \mathrm{wt} \%$ (or 62.22 wt.\% on average), whereas the $\mathrm{Al}_{2} \mathrm{O}_{3}$ range from 5.80 wt.\% to 17.57 wt.\% (or 9.16 wt. $\%$ on average) and $\mathrm{Fe}_{2} \mathrm{O}_{3}$ is from 1.97 wt.\% to 9.07 wt.\% (or 5.09 wt.\% on average). In contrast, the values of $\mathrm{CaO}$ and $\mathrm{MgO}$ typically range from $1.80 \mathrm{wt} . \%$ to $12.00 \mathrm{wt} . \%$ (8.60 wt. $\%$ on average) and 0.98 wt. $\%$ to 4.56 wt. $\%$ (or 2.47 wt. $\%$ on average), respectively. Combined contents of $\mathrm{SiO}_{2}$, $\mathrm{Al}_{2} \mathrm{O}_{3}, \mathrm{Fe}_{2} \mathrm{O}_{3}, \mathrm{CaO}$, and $\mathrm{MgO}$ in CCA exceed $70 \%$, which indicates it could be potentially utilized as a substitute or partial replacement for cement in concrete during the construction of buildings.

According to the ASTM standard C618, the requirement for the use of alternate substances such as CCA as pozzolanic or supplementary cementing materials is that the combined sum of $\mathrm{SiO}_{2}, \mathrm{Al}_{2} \mathrm{O}_{3}$, and $\mathrm{Fe}_{2} \mathrm{O}_{3}$ is $70 \%$ or above (Adesanya et al., 2010; Adesanya, D.A. et al., 2009). 
Table 2. Reaction parameters and reaction conditions for CCA production

\begin{tabular}{|c|c|c|c|c|c|}
\hline References & Method & $\begin{array}{l}\text { Selected } \\
\text { Reactor }\end{array}$ & $\begin{array}{c}\text { Reaction } \\
\text { Temperatur } \\
\text { e }\left({ }^{\circ} \mathrm{C}\right)\end{array}$ & $\begin{array}{l}\text { Ashing } \\
\text { Time } \\
\text { (h) }\end{array}$ & $\begin{array}{l}\text { Particle size } \\
\text { of CCA }(\mu \mathrm{m})\end{array}$ \\
\hline Udoeyo et al. (2003) & Uncontrolled Open Burning & Open Air Burner & $* *$ & $* *$ & 600 \\
\hline Owoyale et al. (2008) & Semi controlled Combustion & Rotary Drum Oven & 750 & $* *$ & 75 \\
\hline Adesanya, D.A. et al. (2009) & Controlled combustion & Blacksmith Furnace & 650 & 8 & $* *$ \\
\hline Wang et al. (2012) & Controlled combustion & Muffle furnace oven & 550 & 6 & 1000 \\
\hline Ettu et al. (2013) & Controlled combustion & $\begin{array}{c}\text { Fabricated } \\
\text { combustion chamber }\end{array}$ & 650 & $* *$ & 650 \\
\hline Jimoh et al. (2013) & $\begin{array}{l}\text { Uncontrolled Open burning/ } \\
\text { Controlled combustion }\end{array}$ & $\begin{array}{l}\text { Open Air Pile/Muffle } \\
\text { Furnace }\end{array}$ & $590-650$ & 10 & $* *$ \\
\hline Oluborode et al. (2015) & Controlled combustion & $\begin{array}{l}\text { Muffle Furnace } \\
\text { Oven }\end{array}$ & 600 & 2 & 75 \\
\hline Akinwumi et al. (2015) & Uncontrolled Burning & Open Air Burner & 560 & 10 & 75 \\
\hline Kamau et al. (2016a) & Uncontrolled Burning & $\begin{array}{l}\text { Open Air Charcoal- } \\
\text { Fired Burner }\end{array}$ & 650 & 8 & $* *$ \\
\hline Apampa (2019) & Uncontrolled Burning & Open Heap Burning & 650 & 5 & 212 \\
\hline Adigun et al. (2019) & Controlled combustion & $\begin{array}{l}\text { Muffle Furnace } \\
\text { Oven }\end{array}$ & 450 & 8 & 250 \\
\hline Bheel et al. (2020) & Controlled combustion & $\begin{array}{c}\text { Muffle Furnace } \\
\text { Oven }\end{array}$ & 600 & 10 & 75 \\
\hline
\end{tabular}

Table 3: Metal oxides and mineral compositions of CCA determined by XRF

\begin{tabular}{|c|c|c|c|c|c|c|c|c|c|c|c|}
\hline References & $\mathrm{SiO}_{2}$ & $\mathrm{Al}_{2} \mathrm{O}_{3}$ & $\mathrm{Fe}_{2} \mathrm{O}_{3}$ & $\mathrm{CaO}$ & MgO & $\mathrm{SO}_{3}$ & $\mathrm{Na}_{2} \mathrm{O}$ & $\mathbf{K}_{2} \mathbf{O}$ & $\mathrm{Mn}_{2} \mathrm{O}_{3}$ & $\mathrm{P}_{2} \mathrm{O}_{5}$ & $\mathrm{TiO}_{2}$ \\
\hline Adesanya, D.A. et al. (2009) & 67.33 & 7.34 & 3.74 & 10.29 & 1.82 & 1.11 & 0.39 & 4.20 & $* *$ & $* *$ & $* *$ \\
\hline Adesanya et al. (2010) & 66.38 & 7.48 & 4.44 & 11.57 & 2.06 & 1.07 & 0.41 & 4.92 & $* *$ & $* *$ & $* *$ \\
\hline Raheem et al. (2011) & 65.39 & 9.14 & 5.61 & 11.53 & 2.33 & 1.10 & 0.48 & 4.92 & $* *$ & $* *$ & $* *$ \\
\hline Jimoh et al. (2013) & 65.40 & 5.80 & 2.97 & 3.70 & 2.30 & 1.10 & 0.48 & 8.39 & 0.06 & 2.45 & 0.61 \\
\hline Mujedu et al. (2014) & 67.41 & 8.39 & 5.00 & 10.87 & 2.27 & 1.59 & $* *$ & $* *$ & $* *$ & $* *$ & $* *$ \\
\hline Oluborode et al. (2015) & 56.39 & 17.57 & 9.07 & 11.47 & 0.98 & 0.55 & 1.91 & 1.98 & $* *$ & $* *$ & $* *$ \\
\hline Kamau et al. (2016a) & 38.80 & 7.90 & 7.40 & 1.80 & 2.10 & 0.59 & 0.90 & 23.50 & $* *$ & $* *$ & $* *$ \\
\hline Singh et al. (2018) & 64.56 & 9.42 & 5.12 & 12.00 & 3.01 & $* *$ & $* *$ & $* *$ & $* *$ & $* *$ & $* *$ \\
\hline Memon et al. (2018) & 61.80 & 6.31 & 1.97 & 4.01 & 3.24 & 1.17 & 0.19 & 5.81 & $* *$ & 4.04 & 0.05 \\
\hline Memon et al. (2019) & 63.73 & 15.08 & 5.32 & 6.56 & 4.56 & $* *$ & 0.10 & 2.05 & $* *$ & 2.50 & 0.06 \\
\hline Bheel et al. (2020) & 67.23 & 6.34 & 5.33 & 10.75 & $* *$ & 1.04 & 0.37 & $* *$ & $* *$ & $* *$ & $* *$ \\
\hline
\end{tabular}

Morphology and microstructure of CCA have been comprehensively characterized in the literature. Figure 3 exhibits the SEM micrograph of CCA recorded by Olafusi et al. (2018). The micrograph reveals that CCA is characterized by polygonal-shaped and agglomerated particles with potential for utilization in concrete composites. Also, the agglomeration potential of CCA could enhance hardening when mixed in concrete composite mixtures. Hence, various researchers have extensively investigated the use of CCA as pozzolanic 
materials for the partial replacement of cement in concrete.

Cement concrete is considered one of the most extensively used construction material worldwide. Typically, the construction of buildings and other infrastructure depends significantly on concrete derived from Ordinary Portland Cement (OPC). The use of concrete cement provides a cost-effective, satisfactory strength and structural performance in building infrastructures worldwide (Adole et al., 2011; Scrivener, 2014; Turner et al., 2013).

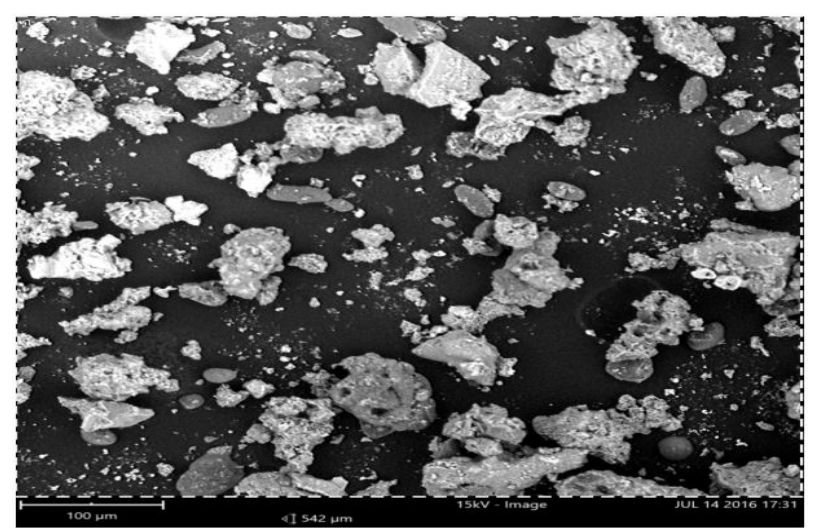

Figure 3. SEM Micrographs of CCA (Olafusi et al., 2018)

An undesired effect of cement production and utilization in the construction industry is the emission of large quantities of carbon dioxide. It is estimated that the cement industry accounts for 5-8\% of anthropogenic $\mathrm{CO}_{2}$ emitted globally, although this could soar significantly over the years (Scrivener, 2014; Turner et al., 2013).

Life cycle analysis of concrete performed by (Sjunnesson, 2005) found that the production of $1 \mathrm{t}$ of concrete aggregate generates approximately $5.4 \mathrm{~kg}(2.75$ $\mathrm{m}^{3}$ ) of $\mathrm{CO}_{2}$. According to $\mathrm{Ma}$ et al. (2016), concrete accounts for $20 \%$ and $12 \%$ of energy and $\mathrm{CO}_{2}$ emissions, respectively, in the United States. Other researchers have reported that the use of cement accounts for about $80 \%$ of $\mathrm{CO}_{2}$ emission attributed to concrete (Latawiec et al., 2018; Turner et al., 2013). Due to the high carbon footprint of cement in concrete, numerous scientists have examined the use of pozzolanic or cementitious materials such as CCA as a replacement for cement, as highlighted in Section 4 of this review paper.

\section{CCA as Cementitious Materials}

Use of CCA as pozzolanic or cementitious materials has been examined in many papers. These studies report on comprehensive findings of the production of CCA from $\mathrm{CA}$ through combustion/incineration technologies. Also described is the characterization of the pozzolanic properties. Lastly, these studies examine the physical, chemical, thermal, and mechanical properties of the concrete or cement-based composites, derived from CCA and OPC. Table 4 provides more detailed findings of the CCA studies reviewed in this paper.

Adesanya, D. et al. (2009) investigated the mechanical properties of corn cob ash (CCA) blended cement concrete.

Table 4. Summary of findings on CCA utilization as Pozzolanic materials

\begin{tabular}{|c|c|c|c|}
\hline References & Objective of the Study & Parameters/ Reaction Conditions & Findings/Conclusions \\
\hline $\begin{array}{l}\text { Adesanya, D. } \\
\text { et al. (2009) }\end{array}$ & $\begin{array}{l}\text { To test the workability } \\
\text { and compressive strength } \\
\text { characteristics of CCA } \\
\text { blended cement } \\
\text { concrete. }\end{array}$ & 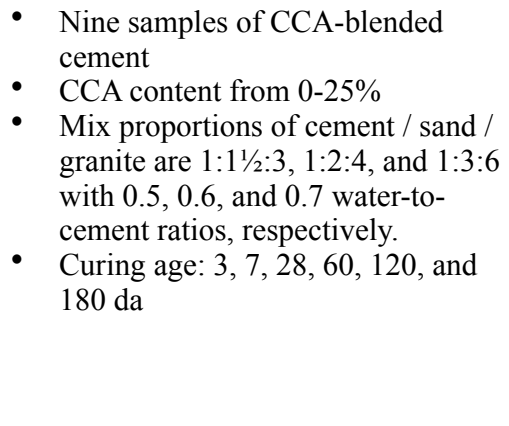 & $\begin{array}{l}\text { - Concrete slump and compacting factor } \\
\text { reduced with increasing CCA content. } \\
\text { Concrete was less workable (stiff) at a } \\
\text { higher CCA percentage. } \\
\text { - Compressive strength of CCA-blended } \\
\text { cement concrete was lower than the } \\
\text { control } \\
\text { - Optimum compressive strength ranged } \\
\text { from } 28.07-57.10 \mathrm{~N} / \mathrm{mm}^{2} \\
\text { 8\% CCA replacement suitable for } \\
\text { blended cement and application in } \\
\text { structural concrete }\end{array}$ \\
\hline
\end{tabular}




\begin{tabular}{|c|c|c|c|}
\hline References & Objective of the Study & Parameters/ Reaction Conditions & Findings/Conclusions \\
\hline $\begin{array}{l}\text { Adesanya et } \\
\text { al. (2010) }\end{array}$ & $\begin{array}{l}\text { To examine the } \\
\text { permeability and impact } \\
\text { of acid attack on CCA } \\
\text { blended cements. }\end{array}$ & $\begin{array}{l}\text { - Permeability and chemical attack } \\
\text { using } \mathrm{HCl} \text { and } \mathrm{H}_{2} \mathrm{SO}_{4} \text {. } \\
\text { Nine CCA blended cements used and } \\
\text { CCA ranged } 0-25 \% \text {. } \\
\text { 0\% CCA replacement represents } \\
\text { ordinary Portland cement (OPC) or } \\
\text { the control. } \\
\text { Water absorption used blended } \\
\text { cement concrete with mix } \\
\text { proportions } 1: 1 \frac{1}{2}: 3,1: 2: 4 \text {, and } 1: 3: 6 \text {. }\end{array}$ & $\begin{array}{l}\text { - CCA blended cement reduced water } \\
\text { absorption. } \\
\text { Optimal reduction was at } 10 \% \text { and } \\
15 \% \text { CCA replacement at } 1: 11 \frac{1}{2}: 3 \text { and } \\
\text { 1:2:4 mix proportions, respectively. } \\
\text { Resistance to chemical attack was } \\
\text { enhanced by adding } 15 \% \text { CCA but } \\
\text { decreased permeability and reduced } \\
\text { weight loss. }\end{array}$ \\
\hline
\end{tabular}

- Water-to-binder (W/B) ratios 0.5-0.7.

- Chemical attack test used $50 \times 50 \times 15$ mm mortar samples with mix proportions $1: 1,1: 2$, and $1: 3$ and $\mathrm{W} /$ $\mathrm{B}$ ratio 0.26-0.29.

Raheem et al. To examine the thermal (2011) conductivity (TC) of CCA blended cement mortar

Olafusi et al. To examine the strength (2012) characteristics of CCA based concrete
- Thermal conductivity decreased with increasing CCA percentage.

- For the mix proportion $1: 1$, the TC reduced from 1.80 to $0.69 \mathrm{~W} / \mathrm{m}{ }^{\circ} \mathrm{C}$ with an increase in CCA from 2 to $25 \%$

- $\mathrm{TC}$ of control $(0 \% \mathrm{CCA})$ was 2.40 $\mathrm{W} / \mathrm{m}{ }^{\circ} \mathrm{C}$.

- CCA blended cements improve the insulation potential of the mortar.

- Physicomechanical properties of changing CCA percentage in cement concrete

- 72 concrete cubes of CCA to Portland cement ratio 0:100, 10:90, and 20:80 were examined.

- Physicomechanical properties tested after casting

- $\quad 35 \mathrm{MPa}$ high strength concrete was designed using CCA for fractional substitution for cement

- A total of 32 concrete cubes (16 samples for $0 \%$ and $10 \%$ partial replacements)

- 8 concrete cylinders (4 samples each of $0 \%$ and $10 \%$ partial replacements).

Ettu et al. To examine the strength

(2013) of CCA based binary

blended cement composites.
- 105 concrete and sandcrete cubes used.

- Dimensions of cubes: $150 \times 150 \times 150$ $\mathrm{mm}$

- Percentage CCA for OPC replacement was $5-25 \%$

- Samples were ground to attain compressive strengths

- Curing Age/Days 3, 7, 14, 21, 28, 50, and 90 .
- Integration of CCA into the blended cement mortar lowers TC

- Addition of CCA enhances the insulation properties of blended cements

- Application of CCA blended cements could enhance thermal comfort of building occupants and save cooling and promote energy conservation.

- Replacement of cement with 10\% CCA showed satisfactory performance without effects on compressive strength.

- The specific gravity of the CCA was 1.15 ,

- Ratios of concrete mix of 1:2:4 at 7 days did not meet the standard strength at 14,21 , and 28 days.

- Split tensile test showed concrete tensile strength is 11-12 times lower than its compressive strength.

- Use of CCA as a partial replacement for cement in concrete promotes waste to wealth innovation.

- CCA concrete takes a longer time to attain desired strength and requires a $\mathrm{W} / \mathrm{B}$ ratio below 0.40 .

- Strength of OPC-CCA binary blended cement concrete was higher than the control at 90 days of curing, for $5-15 \%$ replacement.

- OPC-CCA binary blended cement sandcrete exhibited lower strength compared to the control at early ages up to 28 days.

- Strength increases significantly thereafter and becomes greater than the control after 50 days.

- OPC-CCA binary blended cement sandcrete has potential applications in civil engineering. 


\begin{tabular}{|c|c|c|}
\hline References & Objective of the Study & Parameters/ Reaction Conditions \\
\hline $\begin{array}{l}\text { Price et al. } \\
(2014)\end{array}$ & $\begin{array}{l}\text { To investigate the role of } \\
\text { CCA on the mechanical } \\
\text { properties (i.e., } \\
\text { compressive strength and } \\
\text { workability) and thermal } \\
\text { performance of concrete }\end{array}$ & $\begin{array}{l}\text { - CCA served as the major blending } \\
\text { agent with OPC. } \\
\text { Screening tests to determine the } \\
\text { suitable percentage of CCA for } \\
\text { replacement of cement that complies } \\
\text { with specific standards } \\
\text { Compressive strength, workability } \\
\text { and thermal performance CCA } \\
\text { blended cements examined. }\end{array}$ \\
\hline
\end{tabular}

Suwanmanee To develop, characterize chot et al. and improve the (2015) utilization potential of CCA as cement replacement materials or cementitious-based materials.

Kamau et al. To examine the (2016b) feasibility of utilizing CCA as pozzolanic material in concrete

- Curing time 7, 14, 28, and 56 days.

- CCA percentages of 5, 7.5, 10, 15, and $20 \%$ examined as a replacement for cement.

- Mixes were determined by weight in
Singh et al. To investigate the (2018)

impacts of high temperatures on $\mathrm{CCA}$ as a replacement for cement in concrete

\section{Findings/Conclusions}

- $10 \%$ CCA replacement suitable for replacement of cement or concrete production

- Ratio can enhance the process with no impact on the structural integrity of OPC

- CCA addition to concrete mixtures enhanced compressive strength and workability

- $10 \%$ CCA substantially reduced the thermal conductivity of the concrete mixtures examined.

- Results indicate CCA treated at $600{ }^{\circ} \mathrm{C}$ for $4 \mathrm{~h}$ has the highest fraction of $\mathrm{SiO}_{2}$ $+\mathrm{Al}_{2} \mathrm{O}_{3}+\mathrm{Fe}_{2} \mathrm{O}_{3} \sim 72 \%$

- CCA-600 is a Class N calcined natural pozzolan based on ASTM C618.

- XRD revealed a high content of amorphous silica phase, which was enhanced at increased calcination temperatures.

- Water requirement, as well as the initial and final setting times, increased with increasing CCA percentage.

- CCA- $600{ }^{\circ} \mathrm{C}$ effectively enhanced the compressive and splitting tensile strengths of the concrete as compared to the control. concrete as required in the application.

- Results compared to the control $(0 \%$ CCA or $100 \%$ OPC).

- Durability tests were performed through sulfate elongation by immersing specimens in $5 \% \mathrm{Na}_{2} \mathrm{SO}_{4}$.

- The entire replacements attained significant compressive strengths appropriate for application in structures.

- Tests for sulfate elongation demonstrated CCA is applicable in destructive settings containing $\mathrm{Na}_{2} \mathrm{SO}_{4}$ which is an alkali-based activator.

- High repeatability highlighted the prospects of CCA for effective utilization as pozzolanic material in concrete.

- The influence of high temperatures $\left(150-600{ }^{\circ} \mathrm{C}, \Delta 150^{\circ} \mathrm{C}\right)$ on mechanical properties such as compressive strength was examined.

- Cube samples characterized for $2 \mathrm{~h}$ duration in a muffle furnace.

- Grade M25 concrete and CCA percentages of $0 \%, 5-20 \%(\Delta 5 \%)$ were used for replacing cement examined.

- Water/Binder (W/B) ratio was maintained at 0.45 .
- Compressive strength of the concrete decreases with increasing CCA percentage at normal temperature.

- Trend reversed when the calcination temperature increased to $300{ }^{\circ} \mathrm{C}$ for the all mixes and the control.

- Optimum CCA percentage and calcination temperature for replacing cement in concrete is $10 \%$ and $300{ }^{\circ} \mathrm{C}$, respectively. 


\section{\begin{tabular}{llll}
\hline References & Objective of the Study & Parameters/ Reaction Conditions & Findings/Conclusions
\end{tabular}}

Memon et al. To investigate the eco-

(2019) friendly use of CCA as a partial replacement for sand in concrete.
- CCA with percentages of $0,5,10,15$, and $20 \%$ was used as fine aggregate in eco-friendly concrete mixes.

- Characterization and pozzolan potential were done by physical, thermal, chemical, morphology, and microstructure analyses.

- Mechanical properties of CCA concrete and blends were examined via shrinkage, slump, compressive strength, and slump tests.

- Water absorption, ultrasonic pulse velocity, and density tests were also performed.

- Curing age of CCA concrete and blends; $7,28,56$, and 90 days.
Bheel et al. (2020)
To investigate the impact of CCA and Glass

Powder as binary cementitious materials (BCM) for applications in Concrete $\bullet$

Five mixtures were designed based on equal proportions of CCA and glass powder (GP) for application as $\mathrm{BCM}$ to replace the Portland cement (PC)

- $\quad 10-20 \%$ CCA and control (0BCM i.e., only PC) used as a binder.

- Water to Binder (W/B) ratio was kept constant at 0.50 .

- Total of 75 samples comprising 30 cylinder-shaped and 45 cubes were made.

- Mechanical properties: slump values, compressive and split tensile strengths of the mixtures were examined.

- Curing age varied from 7 to 28 days.

- Sustainability analysis of embodied energy and carbon footprint of BCM mixtures were also examined.
CCA is amorphous, highly porous adequately graded, and devoid of organic contaminations.

- TGA thermal and chemical analyses revealed that CCA exhibits pozzolanic properties for potential application as a partial replacement in concrete.

- Morphology analysis revealed micropores, perforations, and tubules.

- Mechanical properties such as slump and shrinkage increased, whereas the density of fresh concrete declined with increasing CCA percentage.

- The increase in CCA percentage adversely impacted the compressive strength, ultrasonic pulse velocity, and density of the hardened concrete.

- Water absorption also decreased with the curing/testing age.

- Compressive strength of $10 \%$ CCA concrete was $22 \mathrm{MPa}$ after curing age/ time of 28 days.

- Integration of BCM decreased the slump value of concrete.

- $10 \% \mathrm{BCM}$ observed as the optimum based on the enhancement of mechanical properties, namely compressive and split tensile strengths.

- BCM is considered a suitable alternative and sustainable material for reducing the embodied energy and carbon footprint of concrete mixtures.

- Compressive and split tensile strengths of blends with $10 \%$ BCM OPC replacement was enhanced by $8.4 \%$ and $4.9 \%$, respectively.

- BCM utilization in concrete enhances sustainability.

- The blends of concrete with $5-20 \%$ BCM partial replacement for OPC have 4.3-16.8\% lower embodied carbon control compared to non-BCM variants.

- BCM use in mixtures reduced concrete embodied energy by about $21 \%$.
Synthesized CCA-blended cements were examined for compressive strength and workability, using slump and compacting factor tests. Findings indicated that higher CCA content negatively impacted the compacting factor and concrete slump, which revealed that the concrete composite became stiff (i.e., lower or reduced workability). However, the compressive strength of the CCA-blended cement concretes was significantly affected by curing age with improvements observed after 120 days. A separate study by (Adesanya et al., 2010), examined the durability and permeability of CCAblended cement concrete along with the susceptibility of the composites to acid attack. Results showed that the water absorption property of concrete decreased with the addition of CCA-blended cement. Nevertheless, the resistance to chemical attack was improved, particularly upon adding $15 \% \mathrm{CCA}$, although this was accompanied by a simultaneous reduction in the permeability and reduction in weight loss. The lower permeability and weight loss was ascribed to the reaction of the specimens with the acids. Raheem et al. (2011) examined the thermal conductivity of CCA-blended cement-based mortar. Their data showed that the addition of CCA to concrete decreased the thermal conductivity of the blended cement composites, which indicates an increase in the insulation potential of the concrete. Various studies have demonstrated that the addition of pozzolanic materials to concrete composites lowered their thermal conductivity (Stefanidou et al., 2010; Wongkeo et al., 2012). This observation could be ascribed to their high silica content (Raheem et al., 2011) and the high porosity of the concrete upon addition of CCA (Bessenouci et al., 2011). Overall, the study by Raheem et al. (2011) concluded that adding 
CCA-blended cements to concrete could potentially enhance the thermal comfort of building occupants, reduce energy costs, and potential emissions.

Olafusi et al. (2012) investigated the strength properties of CCA based concrete. Results of the study revealed that the increase of CCA percentage added as a partial replacement for cement lowered the compressive strength of the CCA based concrete composite. Authors also noted that as observed with pozzolans, the compressive strength and density increased the curing age. Similarly, Ettu et al. (2013) examined the strength of binary CCA-blended cement composites through empirical and mathematical modelling. Authors revealed that the comprehensive strength of CCA-based composites decreased in the first instance but increased with the curing age. Oluborode et al. (2015) investigated the strength of CCA blended with OPC through several mechanical tests (e.g., specific gravity, aggregate absorption, and particle size distribution) and chemical analysis. The addition of up to $30 \%$ CCA was beneficial to the concrete. Price et al. (2014) examined the effect of CCA on the mechanical properties (i.e., compressive strength and workability) and thermal performance of concrete. Results showed that the compressive strength and workability decreased with the addition of $10 \%$ CCA to concrete blends, whereas the insulation characteristics were improved.

Suwanmaneechot et al. (2015) examined the potential of CCA as supplementary materials for cement in concrete. The authors observed that the higher the composition of CCA used to replace cement, the higher the water requirement was. Original and final setting times were required for the concrete composites. Thermal treatments such as calcination of CCA significantly impacts the content of the pozzolanic oxide $\left(\mathrm{SiO}_{2}\right.$, $\mathrm{Al}_{2} \mathrm{O}_{3}, \mathrm{Fe}_{2} \mathrm{O}_{3}$, and amorphous silica) and provides high specific surface area, which all enhance the suitable engineering properties of concrete. Similarly, Kamau et al. (2016b) investigated the pozzolanic potential of CCA for application in concrete. They found that replacing cement with fractions of OPC yielded composite blends with satisfactory compressive strengths that could be potentially applied in concrete structures. Tests for sulfate elongation revealed that CCA could also be advantageously applied in destructive settings that contain sodium sulphate. According to Donatello et al. (2013), $\mathrm{Na}_{2} \mathrm{SO}_{4}$ is a salt-based source of alkali used to activate pozzolanic materials with little impact on the hydration of cement clinker. The authors also demonstrated that the addition of sodium sulfate lowered the setting times, induction times, as well as enhanced the hydration and compressive strength.

Singh et al. (2018) examined the effect of temperature on the pozzolanic performance and mechanical properties of CCA in concrete. They reported that an increase of CCA content in concrete lowered the compressive strength at normal temperatures; a reverse trend was observed at higher temperatures. This could be ascribed to the higher $\mathrm{SiO}_{2}$ content, which is available to react with calcium oxide generated during cement hydration. Consequently, the compressive strength of the concrete produced with CCA was like the one observed in the literature (Suwanmaneechot et al., 2015). Studies by Memon et al. (2018) and Memon et al. (2019) examined the eco-friendly use of CCA as fractional replacement of sand in cement-based concrete composites. Authors revealed that CCA contains numerous micropores, perforations, and tubules suitable for application as pozzolanic materials. Besides, the increase in the percentage of CCA in the composites resulted in higher shrinkage and slump values, whereas the ultrasonic pulse velocity, compressive strength, and density of the hardened concrete declined accordingly. Overall, the studies demonstrated that CCA is a useful raw material for the replacement of cement in concrete and an environmentally friendly approach for waste disposal and management. In a recent paper, Bheel et al. (2020) addressed the effects of CCA and glass powder, as binary cementitious material (BCM) for the fractional replacement of cement in concrete. Results indicated that $\mathrm{CCA}$ addition reduced the slump values of CCA blended concretes. Optimization showed that 10\% BCM enhanced the compressive strength and the split tensile strength. Furthermore, the BCM used to replace OPC, even at $20 \%$, did not negatively impact the mechanical properties of the concrete.

In general, most authors observed that with the increase in the demand and utilization of OPC, the sustainability of the building construction industry is critically at risk of exacerbating global warming and climate change. Hence, alternative materials are required to reduce sector-related greenhouse gas emissions.

\section{Conclusions}

Our paper presents an overview of the utilization of corn cobs ash (CCA) as cementitious and binary cementitious materials (BCM) in concrete. The basic theories, history, and background on the cultivation, processing, products, and waste streams derived from Corn (Zea mays L.) were described in the first part of the paper. Subsequently, the yield and distribution of solid lignocellulosic wastes, such as corn cobs (CC), were highlighted.

Our literature review indicates that the effective disposal, management, and valorization of $\mathrm{CC}$ remains a major challenge, considering the residue to crop ratio of corn. Current strategies for valorization include the manufacture of chemicals, fuels, livestock feeds, farmhouse beddings, and soil enhancers. Utilization of $\mathrm{CC}$ for the outlined processes and products is ascribed to 
its high elemental, proximate, and heating value properties, such as carbon, volatile matter, fixed carbon, and ash. Although numerous reports have highlighted the problematic nature of the ash content in $\mathrm{CC}$, its chemical composition indicates it as a possible valuable resource for potential utilization as cementitious or binary cementitious materials (BCM). Hence, numerous studies have critically examined the various processing technologies, operational conditions, and selected reactors for the valorization of $\mathrm{CC}$ in corn cob ash (CCA). CCA is suitable for being applied in the construction industry as a partial replacement for cement in concrete, mortar, or other cement-based composites. Before its application as a cement replacement material, CCA is subjected to extensive characterization to elucidate its particle size distribution, chemical, morphological, microstructure, and thermal properties. For analysis, a variety of instrumental methods are used, including X-ray fluorescence (XRF), X-ray diffraction (XRD), Scanning electron microscope (SEM), energy dispersive X-ray (EDX), thermogravimetric analysis (TGA), and others. Based on ASTM C618, potential pozzolanic materials are required to meet the condition; $\mathrm{SiO}_{2}+\mathrm{Al}_{2} \mathrm{O}_{3}+\mathrm{Fe}_{2} \mathrm{O}_{3}=70 \%$, or greater. Our literature review indicates that $\mathrm{CCA}$ typically meets this requirement, which has prompted numerous utilizations of CCA as a replacement for cement. Addition of 10\% CCA to concrete results in compressive strength values ranging from 18-22 $\mathrm{MPa}$ after curing age/time of 28 days. It is also observed that the partial replacement of cement with CCA decreases compressive strength, thermal conductivity ultrasonic pulse velocity, and density of the hardened concrete at normal temperatures. Nonetheless, the thermal treatment or calcination of CCA particularly at high temperatures from 300 to 600 ${ }^{\circ} \mathrm{C}$ along with higher curing age enhances compressive strength owing to the high availability of silica, extended surface area, and porosity.

Overall, the findings indicate that CCA is a low cost, environmentally friendly, and sustainable material for effective application as a pozzolan. Hence, its partial replacement for cement or combination with other materials as BCM could address the twin challenges of greenhouse gas emissions and sustainability of the building construction industry through lower costs and decreased energy demand. Future studies could extend the knowledge on and applicability of CCA by examining its synergistic combination or blending with other waste streams, such as clinker, or spent bleaching earth. Future studies should examine the effect of other parameters, such as calcination temperature (above 600 ${ }^{\circ} \mathrm{C}$ ), particle sizes, and moisture content.

\section{References}

Aboyade, A. O., Hugo, T. J., Carrier, M., Meyer, E. L., Stahl, R., Knoetze, J. H., \& Görgens, J. F. (2011). "Nonisothermal kinetic analysis of the devolatilization of corn cobs and sugar cane bagasse in an inert atmosphere," Thermochimica Acta, 517(1-2): 81-89. doi:10.1016/ j.tca.2011.01.035

Adesanya, D., \& Raheem, A. (2009). "A study of the workability and compressive strength characteristics of corn cob ash blended cement concrete," Construction and Building Materials, 23(1): 311-317.

Adesanya, D., \& Raheem, A. (2010). "A study of the permeability and acid attack of corn cob ash blended cements," Construction and Building Materials, 24(3): 403-409.

Adesanya, D. A., \& Raheem, A. A. (2009). "Development of corn cob ash blended cement," Construction and Building Materials, 23(1): 347-352. doi:10.1016/j.conbuildmat.2007.11.013

Adigun, B. O., Jegede, F. I., \& Tunmilayo Sanya, O. (2019). "Advanced materials development from corncob ash for economic sustainability," International $J$. of Ceramic Engineering \& Science, 2(1): 17-21. doi:10.1002/ces2.10032

Adole, M., Dzasu, W., Umar, A., \& Oraegbune, O. (2011). "Effects of groundnut husk ash-blended cement on chemical resistance of concrete," ATBU Journal of Environmental Technology, 4(1): 23-32.

Ajao, K., Ohijeagbon, I., Adekunle, A., \& Olusegun, H. (2016). "Development of paving tiles compounded with pulverized Corncob charcoal," J. of Production Engineering, 19(2): 101-106.

Akinwumi, I., \& Aidomojie, O. (2015). "Effect of corncob ash on the geotechnical properties of lateritic soil stabilized with Portland cement," International J. of Geomatics and Geosciences, 5(3): 375-392.

Ali, J. B., Musa, A., Danladi, A., Bukhari, M., \& Nyakuma, B. B. (2020). "Physico-mechanical Properties of Unsaturated Polyester Resin Reinforced Maize Cob and Jute Fibre Composites," J. of Natural Fibers doi:10.1080/15440478.15442020.11841062.

Amoakwah, E., Frimpong, K., Okae-Anti, D., \& Arthur, E. (2017). "Soil water retention, airflow and pore structure characteristics after corn cob biochar 
application to a tropical sandy loam," Geoderma, 307189-197.

Andrew, R. M. (2018). "Global CO 2 emissions from cement production," Earth System Science Data, 10(1): 195-217.

Apampa, O. A. (2019). "Environmental benefits of corn cob ash in lateritic soil cement stabilization for road works," African J. of Science, Technology, Innovation and Development, 11(4): 427-431.

Bakharev, D., Pastukhov, A., Volvak, S., \& Kovalev, S. (2020). "Study of seed corn threshing process," Engineering for Rural Development, 191036-1041.

Barontini, F., Biagini, E., Bonini, F., \& Tognotti, L. (2015). "An experimental investigation on the devolatilization behaviour of raw and torrefied lignocellulosic biofuels," Chemical Engineering Transactions, 43.

Benhelal, E., Zahedi, G., Shamsaei, E., \& Bahadori, A. (2013). "Global strategies and potentials to curb $\mathrm{CO}_{2}$ emissions in cement industry," J. of Cleaner Production, 51142-161. doi:https://doi.org/10.1016/ j.jclepro.2012.10.049

Bessenouci, M., Triki, N. B., Khelladi, S., Draoui, B., \& Abene, A. (2011). "The apparent thermal conductivity of pozzolana concrete," Physics Procedia, 2159-66.

Bheel, N., \& Adesina, A. (2020). "Influence of Binary Blend of Corn Cob Ash and Glass Powder as Partial Replacement of Cement in Concrete," Silicon. doi:10.1007/s12633-020-00557-4

Bhuvaneshwari, S., Hettiarachchi, H., \& Meegoda, J. N. (2019). "Crop residue burning in India: Policy challenges and potential solutions," International J. of Environmental Research and Public Health, 16(5): 832.

Biagini, E., Barontini, F., \& Tognotti, L. (2014). "Gasification of agricultural residues in a demonstrative plant: Corn cobs," Bioresource Technology, 173110-116.

Calvo, V. L. V., Giner-Santonja, G., Alonso-Fariñas, B., \& Aguado, J. M. (2021). "The effect of the European Industrial Emissions Directive on the air emission limit values set by competent authorities in the permitting procedure: The case of the Spanish cement industry," Science of the Total Environment, 773145491. doi:https://doi.org/10.1016/j.scitotenv.2021.145491
Chuck, G., Meeley, R., Irish, E., Sakai, H., \& Hake, S. (2007). "The maize tasselseed4 microRNA controls sex determination and meristem cell fate by targeting Tasselseed6/indeterminate spikelet," Nature Genetics, 39(12): 1517-1521.

da Silva, J. C., de Oliveira, R. C., da Silva Neto, A., Pimentel, V. C., \& dos Santos, A. d. A. (2015). "Extraction, addition and characterization of hemicelluloses from corn cobs to development of paper properties," Procedia Materials Science, 8793-801.

Dai, L., Zeng, Z., Tian, X., Jiang, L., Yu, Z., Wu, Q., Ruan, R. (2019). "Microwave-assisted catalytic pyrolysis of torrefied corn cob for phenol-rich bio-oil production over $\mathrm{Fe}$ modified biochar catalyst" $J$. of Analytical and Applied Pyrolysis, 143104691.

Deja, J., Uliasz-Bochenczyk, A., \& Mokrzycki, E. (2010). " $\mathrm{CO}_{2}$ emissions from Polish cement industry," International J. of Greenhouse Gas Control, 4(4): 583-588.

Domínguez-Escribá, L., \& Porcar, M. (2010). "Rice straw management: the big waste," Biofuels, Bioproducts and Biorefining, 4(2): 154-159.

Donatello, S., Fernández-Jimenez, A., \& Palomo, A. (2013). "Very high volume fly ash cements. Early age hydration study using $\mathrm{Na}_{2} \mathrm{SO}_{4}$ as an activator," $J$. of the American Ceramic Society, 96(3): 900-906.

Dutta, D. P., \& Nath, S. (2018). "Low-cost synthesis of $\mathrm{SiO}_{2} / \mathrm{C}$ nanocomposite from corn cobs and its adsorption of uranium (VI), chromium (VI) and cationic dyes from wastewater," J. of Molecular Liquids, 269140-151. doi:10.1016/j.molliq.2018.08.028

Ettu, L., Anya, U., Arimanwa, J., Anyaogu, L., \& Nwachukwu, K. (2013). "Strength of binary blended cement composites containing corn cob ash," International J. of Engineering Research and Development, 6(10): 77-82.

FAOSTAT. (2020). Statistical databases and data-sets of the Food and Agriculture Organization of the United Nations. Retrieved from http://www.fao.org/faostat/en/ Freeling, M., \& Walbot, V. (2013). The Maize Handbook. Germany: Springer Science \& Business Media.

Garantjang, S., Rusdy, M., Hatta, M., \& Nohong, B. (2020). Effect of milking time on milk production and milk quality of dairy cow fed with fermented corn cob. Paper presented at the IOP Conference Series: Earth and Environmental Science. 
Giner-Santonja, G., Calvo, V. V., \& Lepe, G. R. (2019). "Application of AHP and corrective factors for the determination of best available techniques and emission limit values at installation level: A case study in four cement installations," Science of the Total Environment, 660834-840.

Hanle, L. J., Jayaraman, K. R., \& Smith, J. S. (2004). " $\mathrm{CO}_{2}$ emissions profile of the US cement industry" Washington DC: Environmental Protection Agency.

Hardeman, N. P. (1999). Shucks, shocks, and hominy blocks: Corn as a way of life in pioneer America: LSU Press.

Herbst, S. T., \& Herbst, R. (2007). New Food Lover's Companion. USA: Barron's Educational Series, Inc.

Hung, H.-Y., Shannon, L. M., Tian, F., Bradbury, P. J., Chen, C., Flint-Garcia, S. A., Doebley, J. F. (2012). "ZmCCT and the genetic basis of day-length adaptation underlying the post domestication spread of maize," Proceedings of the National Academy of Sciences, 109(28): E1913-E1921.

Iken, J., \& Amusa, N. (2004). "Maize research and production in Nigeria" African Journal of Biotechnology, 3(6): 302-307.

Inmagine Lab. (2021). Dried corn cobs shelled after the corn kernels picked by the machine. Retrieved from https://bit.ly/3qRs3my

Irish, E. E. (1997). "Class II tassel seed mutations provide evidence for multiple types of inflorescence meristems in maize (Poaceae)" American journal of botany, 84(11): 1502-1515.

Jacob, J., \& Buckle, A. (2018). Use of anticoagulant rodenticides in different applications around the world. In Anticoagulant rodenticides and wildlife (pp. 11-43): Springer.

Jain, N., Bhatia, A., \& Pathak, H. (2014). "Emission of air pollutants from crop residue burning in India" Aerosol and Air Quality Research, 14(1): 422-430.

Jansen, C., \& Lübberstedt, T. (2012). "Turning maize cobs into a valuable feedstock" BioEnergy Research, 5(1): 20-31.

Ji, Z., Lin, H., Chen, Y.-f., Dong, Y.-b., \& Imran, M. (2015). "Corn cob modified by lauric acid and ethanediol for emulsified oil adsorption" Journal of Central South University, 22(6): 2096-2105.
Jimoh, Y. A., \& Apampa, O. A. (2013). "An evaluation of the energy consumption and $\mathrm{CO} 2$ emission associated with corn cob ash compared with the cement clinker" Civil and Environmental Research, 3(2): 2863.

Kamau, J., Ahmed, A., Hirst, P., \& Kangwa, J. (2016a). "Suitability of corncob ash as a supplementary cementitious material," International J. of Materials Science and Engineering, 4(4): 215-228.

Kamau, J., Ahmed, A., Hirst, P., \& Kangwa, J. (2016b). "Viability of using corncob ash as a pozzolan in concrete" International J. of Science, Environment and Technology, 5(6): 4532-4544.

Kapoor, M., Panwar, D., \& Kaira, G. S. (2016). Bioprocesses for Enzyme Production Using AgroIndustrial Wastes: Technical Challenges and Commercialization Potential. In G. S. Dhillon \& S. Kaur (Eds.), Agro-Industrial Wastes as Feedstock for Enzyme Production (pp. 61-93). San Diego: Academic Press.

Karl, J. R. (2002). Maize is Not Day Neutral; Day Length and Flowering. The Maize Genetics Cooperation Newsletter.

Kluska, J., Ochnio, M., \& Kardaś, D. (2020). "Carbonization of corncobs for the preparation of barbecue charcoal and combustion characteristics of corncob char," Waste Management, 105560-565.

Knoema. (2020). Maize production quantity. Global Decision-making Data Retrieved from https://bit.ly/ 2Z3FMKR

Latawiec, R., Woyciechowski, P., \& Kowalski, K. J. (2018). "Sustainable concrete performance-CO2emission," Environments, 5(2): 27.

Li, S.-X., Chen, C.-Z., Li, M.-F., \& Xiao, X. (2018). "Torrefaction of corncob to produce charcoal under nitrogen and carbon dioxide atmospheres," Bioresource Technology, 249348-353.

Lu, T., Li, K.-Z., Zhang, R., \& Bi, J.-C. (2015). "Addition of ash to prevent agglomeration during catalytic coal gasification in a pressurized fluidized bed," Fuel Processing Technology, 134414-423.

Ma, F., Sha, A., Yang, P., \& Huang, Y. (2016). "The greenhouse gas emission from Portland cement concrete 
pavement construction in China," International J. of environmental research and public health, 13(7): 632.

Memon, S. A., Javed, U., \& Khushnood, R. A. (2019). "Eco-friendly utilization of corncob ash as partial replacement of sand in concrete," Construction and Building Materials, 195165-177.

Memon, S. A., \& Khan, M. K. (2018). "Ash blended cement composites: Eco-friendly and sustainable option for utilization of corncob ash," J. of Cleaner Production, 175442-455. doi:10.1016/j.jclepro.2017.12.050

Meng, X., Zhou, W., Rokni, E., Zhao, H., Sun, R., \& Levendis, Y. A. (2019). "Effects of air flowrate on the combustion and emissions of blended corn straw and pinewood wastes," J. of Energy Resources Technology, 141(4).

Mikulčić, H., Vujanović, M., Fidaros, D. K., Priesching, P., Minić, I., Tatschl, R., . . Stefanović, G. (2012). "The application of CFD modelling to support the reduction of $\mathrm{CO}_{2}$ emissions in cement industry," Energy, 45(1): 464-473.

Mujedu, K., Adebara, S., \& Lamidi, I. (2014). "The use of corn cob ash and saw dust ash as cement replacement in concrete works," International J. of Engineering and Science, 3(4): 22-24.

Munir, S., Sattar, H., Nadeem, A., \& Azam, M. (2017). "Thermal and kinetic performance analysis of corncobs, Falsa sticks, and Chamalang coal under oxidizing and inert atmospheres," Energy Sources, Part A: Recovery, Utilization, and Environmental Effects, 39(8): 775-782.

Nasser, W. S. A. (2018). "The Potential of Natural Products in Control of Domestic Rodents and Their Zoonotic Diseases," CU Thesis.

Nethaji, S., Sivasamy, A., \& Mandal, A. (2013). "Preparation and characterization of corn cob activated carbon coated with nano-sized magnetite particles for the removal of $\mathrm{Cr}$ (VI)," Bioresource Technology, 13494-100.

NIIR. (2006). Wheat, Rice, Corn, Oat, Barley and Sorghum Processing Handbook (Cereal Food Technology). National Institute of Industrial Research, India: Asia Pacific Business Press.

NWE. (2020). Maize Crop. Retrieved from https://bit.ly/ 3rEMGCy
Nyakuma, B. B., Ahmad, A., Johari, A., Abdullah, T. A., Oladokun, O., \& Alkali, H. (2017). "Fluidised Bed Gasification and Chemical Exergy Analysis of Pelletised Oil Palm Empty Fruit Bunches," Chemical Engineering Transactions, 56(1): 1159-1164.

Olafusi, O. S., Kupolati, W. K., Sadiku, R., Snyman, J., \& Ndambuki, J. M. (2018). Characterization of corncob ash (CCA) as a pozzolanic material. In: IJCET.

Olafusi, O. S., \& Olutoge, F. A. (2012). "Strength properties of corn cob ash concrete," J. of Emerging Trends in Engineering and Applied Sciences, 3(2): 297-301.

Oluborode, K., \& Olofintuyi, I. (2015). "Strength Evaluation of Corn cob ash in a blended Portland cement," International Journal of Engineering and Innovative Technology (IJEIT), 4(12).

Owoyale, O., \& Yusufu, M. (2008). "Crushing strength of concrete using maize cob ash cement as binder," FUTY Journal of the Environment, 3(1): 13-18.

Pallas, B. D., Keys, D. M., Bradley, M. P., VernascoPrice, E. J., Sanders, J. D., Allen, P. S., \& Freeman, Z. T. (2020). "Compressed Paper as an Alternative to Corn Cob Bedding in Mouse (Mus musculus) Cages," J. of the American Association for Laboratory Animal Science, 59(5): 496-502.

Porteiro, J., Patino, D., Collazo, J., Granada, E., Moran, J., \& Miguez, J. (2010). "Experimental analysis of the ignition front propagation of several biomass fuels in a fixed-bed combustor," Fuel, 89(1): 26-35.

Price, A., Yeargin, R., Fini, E., \& Abu-Lebdeh, T. (2014). "Investigating effects of the introduction of corncob ash into portland cement concrete: mechanical and thermal properties," American J. of Engineering and Applied Science, 7133-144.

Raheem, A., \& Adesanya, D. (2011). "A study of thermal conductivity of corn cob ash blended cement mortar," The Pacific J. of Science and Technology, 12(2): 106-111.

Saldivar, S. O. S. (2016). Cereals: "Types and Composition," In B. Caballero, " In P. M. Finglas, \& F. Toldrá (Eds.), Encyclopedia of Food and Health (pp. 718-723). Oxford: Academic Press.

Saldivar, S. O. S., \& Perez-Carrillo, E. (2016). "Maize," In B. Caballero, P. M. Finglas, \& F. Toldrá (Eds.), 
Encyclopedia of Food and Health (pp. 601-609). Oxford: Academic Press.

Salvador-Reyes, R., \& Clerici, M. T. P. S. (2020). "Peruvian Andean maize: General characteristics, nutritional properties, bioactive compounds, and culinary uses" Food Research International, 130108934.

Samanta, A., Senani, S., Kolte, A. P., Sridhar, M., Sampath, K., Jayapal, N., \& Devi, A. (2012). "Production and in vitro evaluation of xylooligosaccharides generated from corn cobs," Food and Bioproducts Processing, 90(3): 466-474.

Santiago-De la Rosa, N., Mugica-Álvarez, V., CerecedaBalic, F., Guerrero, F., Yáñez, K., \& Lapuerta, M. (2017). "Emission factors from different burning stages of agriculture wastes in Mexico," Environmental Science and Pollution Research, 24(31): 24297-24310.

Sattar, H., Muzaffar, I., \& Munir, S. (2020). "Thermal and kinetic study of rice husk, corn cobs, peanut crust and Khushab coal under inert (N2) and oxidative (dry air) atmospheres," Renewable Energy, 149794-805.

Schorcht, F., Kourti, I., Scalet, B. M., Roudier, S., \& Sancho, L. D. (2013). "Best available techniques (BAT) reference document for the production of cement, lime and magnesium oxide," European Commission Joint Research Centre Institute for Prospective Technological Studies, Luxembourg.

Scrivener, K. L. (2014). "Options for the future of cement," Indian Concr. J., 88(7): 11-21.

Shariff, A., Mohamad Aziz, N. S., Ismail, N. I., \& Abdullah, N. (2016). "Corn Cob as a Potential Feedstock for Slow Pyrolysis of Biomass," J. of Physical Science, 27(2).

Shen, Z., Zhang, J., Hou, D., Tsang, D. C., Ok, Y. S., \& Alessi, D. S. (2019). "Synthesis of MgO-coated corncob biochar and its application in lead stabilization in a soil washing residue," Environment International, 122357-362.

Shiferaw, B., Prasanna, B. M., Hellin, J., \& Bänziger, M. (2011). "Crops that feed the world 6. Past successes and future challenges to the role played by maize in global food security," Food Security, 3(3): 307. doi:10.1007/ s12571-011-0140-5

Singh, K., Singh, J., \& Kumar, S. (2018). "A Sustainable Environmental Study on Corn Cob Ash Subjected To
Elevated Temperature," Current World Environment, 13(1): 144-150. doi:10.12944/cwe.13.1.13

Sjunnesson, J. (2005). "Life cycle assessment of concrete".

Song, M., Jin, B., Xiao, R., Yang, L., Wu, Y., Zhong, Z., \& Huang, Y. (2013). "The comparison of two activation techniques to prepare activated carbon from corn cob," Biomass and Bioenergy, 48250-256.

Stefanidou, M., Assael, M., Antoniadis, K., \& Matziaroglou, G. (2010). "Thermal Conductivity of Building Materials Employed in the Preservation of Traditional Structures," International J. of Thermophysics, 31(4): 844-851. doi:10.1007/ s10765-010-0750-8

Suwanmaneechot, P., Nochaiya, T., \& Julphunthong, P. (2015). "Improvement, characterization and use of waste corn cob ash in cement-based materials, " Paper presented at the IOP Conference Series: Materials Science and Engineering.

Turner, L. K., \& Collins, F. G. (2013). "Carbon dioxide equivalent $\left(\mathrm{CO}_{2}\right.$-e) emissions: A comparison between geopolymer and OPC cement concrete," Construction and Building Materials, 43125-130.

Udoeyo, F. F., \& Abubakar, S. A. (2003). "Maize-cob ash as filler in concrete," $J$. of Materials in Civil Engineering, 15(2): 205-208.

Valderrama, C., Granados, R., Cortina, J. L., Gasol, C. M., Guillem, M., \& Josa, A. (2012). "Implementation of best available techniques in cement manufacturing: a life-cycle assessment study." J. of Cleaner Production, 2560-67.

von Cossel, M., Möhring, J., Kiesel, A., \& Lewandowski, I. (2017). "Methane yield performance of amaranth (Amaranthus hypochondriacus L.) and its suitability for legume intercropping in comparison to maize (Zea mays L.)," Industrial Crops and Products, $103107-121$. doi:https://doi.org/10.1016/ j.indcrop. 2017.03 .047

Wachirapakorn, C., Pilachai, K., Wanapat, M., Pakdee, P., \& Cherdthong, A. (2016). "Effect of ground corn cobs as a fibre source in total mixed ration on feed intake, milk yield and milk composition in tropical lactating crossbred Holstein cows," Animal Nutrition, 2(4): 334-338. 
Wang, L., Hustad, J. E., \& Grønli, M. (2012). "Sintering Characteristics and Mineral Transformation Behaviors of Corn Cob Ashes," Energy \& Fuels, 26(9): 5905-5916. doi:10.1021/ef300215x

Wasaya, A., Tahir, M., Ali, H., Hussain, M., Yasir, T. A., Sher, A., \& Ijaz, M. (2017). "Influence of varying tillage systems and nitrogen application on crop allometry, chlorophyll contents, biomass production and net returns of maize (Zea mays L.)," Soil and Tillage Research, 17018-26.

Wongkeo, W., Thongsanitgarn, P., Pimraksa, K., \& Chaipanich, A. (2012). "Compressive strength, flexural strength and thermal conductivity of autoclaved concrete block made using bottom ash as cement replacement materials," Materials \& Design, 35434-439.

Yadav, O., Hossain, F., Karjagi, C., Kumar, B., Zaidi, P., Jat, S., Kumar, P. (2015). "Genetic improvement of maize in India: retrospect and prospects," Agricultural Research, 4(4): 325-338.

Young, T. E., Giesler-Lee, J., \& Gallie, D. R. (2004). "Senescence-induced expression of cytokinin reverses pistil abortion during maize flower development," The Plant J., 38(6): 910-922.

Yu, Y., Fu, H., \& Yu, J. (2015). "DEM-based simulation of the corn threshing process," Advanced Powder Technology, 26(5): 1400-1409.

Zhang, J., Liu, G., Chen, B., Song, D., Qi, J., \& Liu, X. (2014). "Analysis of $\mathrm{CO}_{2}$ emission for the cement manufacturing with alternative raw materials: an LCAbased framework," Energy Procedia, 612541-2545.

Zhang, L., Tian, L., Sun, R., Liu, C., Kou, Q., \& Zuo, H. (2019). "Transformation of corncob into furfural by a bifunctional solid acid catalyst," Bioresource Technology, 27660-64.

Zhang, R.-Q., Ma, C.-L., Shen, Y.-F., Sun, J.-F., Jiang, K., Jiang, Z.-B., He, Y.-C. (2020). "Enhanced biosynthesis of furoic acid via the effective pretreatment of corncob into furfural in the biphasic media," Catalysis Letters, 150(8): 2220-2227. 